\title{
Theories of Leadership and Church Management
}

\author{
Joseph Tong \\ Counselor Sekolah Tinggi Teologi Excelsius \\ josephtongits@gmail.com
}

\begin{abstract}
Management is the integration and coordination of resources to effectively move the organization towards the desired goals. The concepts and key elements in management are organizations. This organization is also divided into two namely: voluntary organizations and voluntary organizations. The objectives of this management are: (1) Vision and mission for existence; (2) Objectives and targets; (3) The desired destination and floating destination. Management effectiveness refers to how well an organization reaches its goals over a period of time. This emphasizes goals or mission (long distance) and goals (short term). Effectiveness contrasts with efficiency. Efficiency is a short-term measure of how well an organization uses resources. Healthy organization management must be effective and efficient. Leadership relates to people, while management pays more attention to tasks and performance. As far as the organization is concerned, these two things have the same function in promoting the well-being and development of healthy organizations to achieve organizational goals.
\end{abstract}

Keywords: Leadership; Management; Church

\begin{abstract}
Abstrak
Manajemen adalah integrasi dan koordinasi sumber daya untuk menggerakkan organisasi secara efektif menuju tujuan yang diinginkan. Adapun konsep dan elemen kunci dalam manajemen yaitu organisasi. Organisasi ini pun dibagi menjadi dua yakni: organisasi sukarela dan organisasi tidak sukarela. Tujuan dari manajemen ini adalah: (1) Visi dan misi untuk eksistensi; (2) Tujuan dan target; (3) Tujuan yang diinginkan dan tujuan mengambang. Efektivitas manajemen mengacu pada seberapa baik sebuah organisasi untuk mencapai tujuannya selama periode waktu tertentu. Hal ini menekankan pada tujuan atau misi (jarak jauh) dan tujuan (jangka pendek). Efektivitas kontras dengan efisiensi. Efisiensi adalah ukuran jangka pendek seberapa baik sebuah organisasi menggunakan sumber daya. Manajemen organisasi yang sehat harus efektif dan efisien. Kepemimpinan berkaitan dengan orang, sedangkan manajemen lebih memperhatikan tugas dan kinerjanya. Sejauh menyangkut organisasi, dua hal ini memiliki fungsi yang sama dalam mempromosikan kesejahteraan dan pengambangan organisasi yang sehat untuk mencapai tujuan organisasi.
\end{abstract}

Kata Kunci: Kepemimpinan; Manajemen; Gereja 


\section{PENDAHULUAN}

Seorang pemimpin adalah orang yang menunjukkan jalan untuk melangkah, membimbing, mengarahkan jalan anggota baik sebelum dan sesudah urusan itu berjalan. Dari sudut pandang praktis, pemimpin adalah seseorang yang memiliki tujuan yang jelas dan tahu ke mana tujuannya, dan mampu menyakinkan orang lain untuk ikut dengannya. Secara operasional dapat dijabarkan sebagai berikut: saat perilaku A menyebabkan perubahan perilaku B, oleh karena itu kemudian A dikatakan sebagai pemimpin B; sedangkan B adalah pengikut A. Pengertian pemimpin yang kontemporer berkata bahwa: (1) Pemimpin adalah orang yang dapat mengelola dan menguasai kontradiksi dan paradoks secara efektif untuk memaksimalkan potensi dalam mencapai tujuan organisasi; (2) Inti kepemimpinan yang efektif adalah konsep kekuasaan. Kepemimpinan adalah kemampuan untuk mempengaruhi - untuk menyelesaikan sesuatu meskipun ada perlawanan dari orang lain.

\section{METODOLOGI PENELITIAN}

Dalam meneliti artikel ini, penulis menggunakan metode penelitian pendekatan studi literatur.

\section{ANALISIS DAN HASIL PENELITIAN}

Tipe Budaya Perusahaan atau Organisasi

Ada empat tipe budaya perusahaan atau organisasi sebagai berikut: (1) Budaya Macho (budaya berorientasi prestasi): dunia individualis yang secara teratur mengambil risiko tinggi dan mendapatkan umpan balik cepat mengenai apakah tindakan mereka yang benar atau salah; (2) Budaya kerja keras atau bermain (fun oriented culture): kesenangan dan tindakan adalah peraturannya, karyawan hanya mengambil sedikit risiko, semua dengan umpan balik yang cepat, budaya mendorong karyawan untuk mempertahankan aktivitas berisiko rendah yang berelatif rendah; (3) Budaya umpan balik dengan risiko tinggi (budaya patristik): budaya dengan keputusan taruhan besar, di mana tahun-tahun berlalu sebelum karyawan mengetahui apakah keputusan telah berhasil; (4) Budaya proses (budaya membangun moralitas): sedikit atau tidak ada umpan balik, karyawan hanya memiliki sedikit atau sama sekali tidak mengetahui hasilnya. Mengembangkan cara atau sikap bukan hasilnya.

\section{$\underline{\text { Sifat Manajemen }}$}

Dalam manajemen ada sebuah sumber daya organisasi. Sumber daya organisasi ini meliputi orang-orangnya (anggota dan personil kunci), sumber keuangannya (aset modal dan kapitalisasi 
yang bertujuan untuk memaksimalkan potensi), teknologinya (fasilitas, peralatan, jabatan anggota teknokratiknya, dan lainlain), hingga klien atau pelanggannya (orangorang yang dilayaninya).

Setelah adanya sumber daya organisasi, barulah dikenal adanya aksi organisasi atau perilaku. Perilaku ini pun dibagi menjadi dua, yaitu: aksi (teleologis) dan kegiatan (fenomenal). Bedakan (belaka) hidup dan hidup (gencar, kuat, dinamis).

Koordinasi dan integrasi merupakan hal yang penting di dalam organisasi. Selain itu kombinasi yang tepat adalah entitas komposisi (komposisi homogenitas atau heterogenitas). Integritas yang tepat adalah integrasi internal menjadi entitas yang tidak dapat dipisahkan.

\section{Pentingnya Manajemen}

Organisasi versus Organisasi. Disini terjadi pertumbuhan versus perkembangan; free-flow versus terencana dan terstruktur; panduan versus kontrol. Kepentingan manajemen mencangkup: (1) Tugas kelompok (ekternal, terukur) dan dinamika kelompok (internal atau potensial); (2) Mengelola kegiatan (manajemen) dan mengelola personil (kepemimpinan); menciptakan atmosfir terbaik yang kondusif bagi produksi; (3) Menemukan dan memaksimalkan potensi (Ams. 29:18).

\section{$\underline{\text { Kepemimpinan dan Aktivitas Manajerial }}$}

Ada sepuluh tugas kepemimpinan dan aktivitas manajerial. Kesepuluh tugas itu adalah sebagai berikut: (1) Pengambil keputusan: keputusan sebagai tindakan untuk memilih tindakan atas tindakan lain yang mungkin dilakukan (keputusan tugas dan keputusan personalia); (2) Perencana: berencana menentukan arah organisasi. Hal ini berorientasi kepada masa depan dengan memaksimalkan pemanfaatan masa lalu (perencanaan berorientasi tugas, perencanaan berorientasi personalia, dan perencanaan organisasi); (3) Penyelenggara: koordinasi, pembagian tugas, penanggungjawab, struktur dan pemeliharaan; (4) Prosesor informasi: berfungsi sebagai sumber informasi, sumber daya manusia dan akal pusat rujukan, fasilitator, pusat relay komunikasi, dan pusat pengolahan data. Menghindari adanya kesalahan dalam komunikasi; (5) Monitor dan pengontrol: memastikan bahwa organisasi tersebut beroperasi sesuai rencana, sesuai jadwal dan dalam kondisi kerja yang baik. Memperhatikan hasil dan masalah yang tak terduga. Membuat penyesuaian yang diperlukan untuk mencapai tujuan lebih dari sasaran. Memanipulasi variabel, cukup fleksibel untuk beradaptasi dan mengakomodasi variabel baru; (7) Ahli lingkungan: perhatian ekologis, menggabungkan variabel lingkungan dan 
kekuatan menjadi gambaran yang harmonis; (8) Konduktor dan bukan direktur: memanfaatkan sebaik-baiknya semua instrumentasi dan situasi yang ada; (9) Pusat organisasi: memanfaatkan sebaik-baiknya semua instrumentasi situasi yang ada; (10) Point of reference. Ketika seorang pemimpin atau manajer berhasil menjalankan sepuluh tugas kepemimpinan dan aktivitas manajerial seperti di atas, barulah ia dapat disebut pemimpin atau manajer yang inovatif.

\section{$\underline{\text { Tipe Budaya Perusahaan atau Organisasi }}$}

Ada empat tipe budaya perusahaan atau organisasi sebagai berikut: (1) Budaya Macho (budaya berorientasi prestasi): dunia individualis yang secara teratur mengambil risiko tinggi dan mendapatkan umpan balik cepat mengenai apakah tindakan mereka yang benar atau salah; (2) Budaya kerja keras atau bermain (fun oriented culture): kesenangan dan tindakan adalah peraturannya, karyawan hanya mengambil sedikit risiko, semua dengan umpan balik yang cepat, budaya mendorong karyawan untuk mempertahankan aktivitas berisiko rendah yang berelatif rendah; (3) Budaya umpan balik dengan risiko tinggi (budaya patristik): budaya dengan keputusan taruhan besar, di mana tahun-tahun berlalu sebelum karyawan mengetahui apakah keputusan telah berhasil; (4) Budaya proses (budaya membangun moralitas): sedikit atau tidak ada umpan balik, karyawan hanya memiliki sedikit atau sama sekali tidak mengetahui hasilnya. Mengembangkan cara atau sikap bukan hasilnya.

\section{Teknik Pengembangan Organisasi}

Teknik Interpersonal (Conciliatory)

Metode dari teknik interpersonal ini adalah bangunan sensitif (pertemuan kelompok), team building (dinamika kelompok), serta manajemen dan resolusi konflik interpersonal dan antar kelompok (proses kelompok).

Tujuannya adalah untuk pengurangan dan pemanfaatan konflik, meningkatkan kolaborasi, meningkatkan kemampuan pengambilan keputusan, meningkatkan partisipasi.

\section{Teknik Struktural}

Dalam teknik struktural ini manajemen oleh tujuan (MBO) melibatkan bawahan dan menetapkan tujuan tugas. Pengayaan kerja melibatkan bawahan dalam partisipasi dalam evaluasi pekerjaan, perancangan dan perencanaan. Selain itu juga ada proses konsultasi. Proses ini mengubah proses pola komunikasi, peran, prosedur pemecahan masalah, peraturan organisasi, hubungan otoritas, dan rantai komando. Pada tahap ini, konsultan luar biasanya diperlukan untuk menjadi pengamat dan fasilitator.

Tujuan dari teknik struktural ini adalah mengurangi kontrol yang berlebihan, 
identifikasi tujuan organisasi super ordinat, meningkatkan otonomi individu, dan memperbaiki arus komunikasi.

\section{$\underline{\text { Gambaran dari Teori-teori Manajemen }}$}

Kebutuhan manajemen melingkupi:

(1) Kelangsungan hidup versus pemenuhan;

(2) Gaya militer versus gaya keluarga; (3)

Tugas berorientasi versus orang-orang yang berorientasi.

Dalam manajemen dan manipulasi ada model integratif (melihat sifat dasar organisasi sebagai kesatuan integral) versus model disintegratif (menciptakan konflik dan kondisi disintegratif untuk mendapatkan kontrol maksimal). Kemudian, ada juga konsolidasi versus non-konsolidasi.

\section{Teori Manajemen Klasik}

Teori Ekonomi Rasional

Pencentus teori ekonomi rasional yang bernama Adam Smith berkata bahwa orang memilih tindakan yang memaksimalkan ekonomi pahala mereka. Asumsi dasar teori ekonomi rasional adalah pandangan pesimis tentang sifat manusia dan kontrol rasional emosi. Semua pria termotivasi oleh insentif ekonomi. Manajemen adalah memaksimalkan (moneter) kepentingan. Organisasi mengendalikan insentif ini, individu merupakan sumber pasif untuk dimanipulasi, dikendalikan dan dimotivasi oleh organisasi. Emosi harus dikendalikan oleh rasionalitas ekonomi. Organisasi dirancang untuk mengendalikan emosi irasional, tidak dapat diprediksi, perilaku disfungsi anggotanya.

\section{Teori Manajemen Ilmiah}

Teori manajemen ilmiah ini dikembangkan oleh Frederick W. Taylor. Teori ini memiliki elemen dasar bahwa setiap pekerjaan terdiri dari banyak elemen; ada cara ilmiah untuk melakukan setiap elemen. Pekerja harus dilatih secara ilmiah dan disesuaikan dengan pekerjaan masingmasing. Setiap pekerjaan harus diawasi secara ketat dan harus ada koordinasi yang ketat antara manajemen dan pekerja. Pembagian kerja, pengawasan, dan istruksi yang jelas diperlukan untuk memastikan ketentuan dan kinerja.

Pandangan mekanistik alam menekankan cara terbaik untuk melakukan setiap pekerjaan dengan sedikit usaha. Hasilnya dalam teori manajemen seperti itu adalah pengembangan studi gerak-waktu, dan sistem insentif. Prinsip administrasi yang dikembangkan dalam konteks ini adalah penekanan pada logika, rasionalitas, dan konsistensi. Jadi kemudian secara singkat dapat disebut sebuah sistem jalur produksi.

\section{Teori Organisasi Birokrasi}

Berdasarkan teori sosial Max Weber, teori ini merupakan reaksi terhadap penyalahgunaan kekuasaan manajerial. Pembagian kerja dengan spesialisasi 
fungsional dalam kerangka hierarki kewenangan yang didefinisikan dengan baik. Mengembangkan sistem peraturan yang mencakup hak dan kewajiban pekerja, dan prosedur untuk menangani situasi kerja. Hubungan kerja impersonal antara semua orang berdasarkan kinerja teknis.

Tugas manajemen di sini adalah untuk mengetahui kapan saja organisasi tersebut dapat melakukan dan menyelesaikan pekerjaannya. Ketika organisasi terlalu besar, semua pemain merasa tidak mungkin mengetahui tugas mereka kecuali satu aturan disajikan dengan jelas. Teori ini mengansumsikan bahwa perilaku karyawan konsisten jika aturan tersebut ditetapkan dengan jelas. Bila posisi sedang fokus, bukan orangnya, maka akan ada kelanjutan organiasi. Meskipun teori ini memberikan pemeriksaan dan keseimbangan yang baik, ada kekurangan yang membuat terlalu banyak pita merah dan dokumen. Ini juga tidak memiliki perhatian dan keterlibatan pribadi manusia. Organisasi berjalan seperti mesin besar. Kesesuaian dan kebijakan merupakan elemen terpenting dalam organisasi.

\section{$\underline{\text { Evaluasi Teori Manajemen Klasik }}$}

Teori manajemen klasik telah berlangsung selama beberapa dekade sebagai gagasan dasar praktik manajemen. Mereka berasumsi bahwa orang termotivasi terutama oleh penghargaan ekonomi. Pengaturan sosio-ekonomi pada awal abad ke-20 memang menjamin teori semacam itu beroperasi dengan lancar (begitu pula situasi di negara-negara dunia ketiga yang belum berkembang). Modernisasi menyatukannya dan penekanan pemenuhan eksistensi manusia telah membuktikan bahwa teori semacam itu mulai ketinggalan zaman.

\section{$\underline{\text { Teori Neo-Klasik dan Teori Manajemen }}$ Modern \\ Teori Manajemen Neo-Klasik}

Sebagai hasil dari perubahan sosial setelah Perang Dunia I, sekelompok penelitian berpusat pada kebutuhan sosial, dorongan, dan sikap individu. Selain penekanan pada rasionalitas dan insentif ekonomi, mereka mengambil aspek emosional dan manusia ke dalam akun manajemen. Ini memulai gerakan pendekatan manusia berorientasi.

Banyak penelitian menemukan bahwa selain insentif rasional dan ekonomi, ada beberapa variabel, yang menentukan hasil kinerja pekerja, seperti kondisi kerja (Hawthorne Effects: Linght), suasa kerja (koordinasi warna, dan dampak warna pada kinerja kerja), hubungan pekerja, dukungan kelompok, dan faktor non-ekonomi lainnya, yang mempengaruhi perilaku karyawan di tempat kerja. Semua ini menujukkan bahwa para pekerja tidak pernah meninggalkan perasaan mereka, sikap, dan emosi mereka di 
rumah. Perilaku manusia itu rumit, tidak sederhana.

Pandangan orang sosial menekankan kebutuhan sosial, teori ini menetapkan strategi untuk meningkatkan kemampuan pengawas yang menangani pekerja tersebut. Unsur dasar dalam tampilan orang sosial dapat dilihat sebagai berikut: individu dimotivasi oleh kebutuhan sosial; orang mendapatkan identitas mereka melalui hubungan interpersonal. Orang-orang cenderung tidak puas jika pekerjaan menjadi rutinitas. Mereka lebih responsif terhadap tekanan kelompok sebaya daripada insentif dan kontrol manajemen.

Teori ini disebut teori neo-klasik karena mengansumsikan bahwa dengan memperbaiki hubungan manusia dalam memperlakukan pekerja seperti individu, pekerja akan merespon prinsip insentif ekonomi dengan lebih baik.

\section{$\underline{\text { Teori Manajemen Modern }}$}

Kekhawatiran yang mendasar mengenai teori manajemen modern ini menyoroti kompleksitas organisasi morden. Mengakui baik komplesitas individu dan organisasi, ia menekankan motivasi, kebutuhan, aspirasi dan potensin individu dan kelompok.

Orang-orang sangat kompleks dan bervariasi. Interaksi antara individu dapat bervariasi dan bermanfaat jika dapat membuat kecocokan yang baik. Oleh karena itu teori manajemen menekankan strategi manajerial yang rumit untuk menangani orang dan organisasi.

\section{$\underline{\text { Teori Utama }}$}

Teori Sistem

Teori sistem adalah suatu sistem kesatuan yang terdiri dari dua atau lebih bagian yang saling bergantung untuk berinteraksi membentuk organisme yang berfungsi.

Bagian yang saling tergantung: tidak ada sesuatu dalam organisasi yang beroperasi dengan sendirinya. Seperti organisme, setiap bagian tidak independen, tapi saling bergantung satu salam lain. Tidak masalah bisa memiliki satu penyebab, semua bekerja dalam konteks sistem. Setiap organisasi adalah sistem terbuka, yang berarti berinteraksi secara teratur dengan kekuatan eksternal, yang berdampak pada praktik organisasi. Sebaliknya, sebuah organisasi juga berdampak pada lingkungannya. Interaksi antara organisasi dan lingkungannya membuat organiasi menjadi sistem terbuka. Sebagai sistem terbuka, sebuah organisasi berubah secara terartur sebagai hasil interaksi dengan lingkungan. Manajer harus menyadari perubahan tersebut dan melakukan penyesuaian yang diperlukan. Ketergantungan semua 
komponen membuat penyesuaian kebutuhan mendesak.

\section{Teori Kontingensi}

Teori ini menekankan tidak adanya satu cara terbaik untuk mengelola dan menekankan kebutuhan akan strategi manajerial berdasarkan semua fakta yang relevan. Seorang manajer harus selalu mempertimbangkan setiap situasi secara terpisah. Individu dimotivasi oleh pengaruh di sekitar mereka; dengan memenuhi kebutuhan individu dan memanipulasi pengaruh lingkungan, keterampilan manajerial yang baik dapat dikembangkan. Hal ini menunjukkan bahwa manajer harus menjadi pemimpin yang fleksibel, terampil dalam mengidentifikasi kebutuhan dan mencocokan kebutuhan dan motivasi. Melakukan hal yang benar dan pada waktu yang tepat.

Manajer harus menyusun dan merancang organisasi agar sesuai dengan situasi. Struktur yang efektif bergantung pada jenis (kontingen) lingkungan tempat organisasi beroperasi. Ide dasarnya adalah fleksibilitas.

\section{$\underline{\text { Humanisme Organisasi }}$}

Teori Y: Self-directive-ness milik Maslow dan McGregor berkata bahwa filosofi yang mendasari adalah individu perlu menggunakan semua kemampuan dan keterampilan kreatif mereka di tempat kerja maupun di rumah. Jadi teori ini dapat disebut teori aktualisasi diri.

Hirarki Maslow tentang kebutuhan manusia menyatakan bahwa ada lima hal, yaitu: (1) Kelangsungan hidup, keamanan, dan kebutuhan untuk aman; (2) Kebutuhan sosial dan hubungan; (3) Ego dan kebutuhan harga diri; (4) Kebutuhan untuk independen; (5) Kebutuhan aktualisasi diri - sepenuhnya menggunakan semua kemampuan pribadi.

$$
\text { Semua karyawan (individu) }
$$

termotivasi sendiri, jika diberi kesempatan. Mereka akan bereaksi negatif terhadap kontrol dari luar. Mengingat lingkungan yang kondusif, setiap individu akan secara kreatif mengintegrasikan tujuannya dengan tujuan organisasi.

\section{$\underline{\text { Ilmu Manajemen }}$}

Menekankan penggunaan teknik kuantitatif (analisis statistik) untuk membantu pengembalian keputusan dalam organisasi. Mempekerjaan alat kuantitatif untuk menganalisis dan menilai informasi dan data yang dikumpulkan untuk memberikan pemahaman yang lebih baik mengenai perilaku organisasi dan strategi pemecahan masalah. Sangat tergantung pada metodologi dan keterampilan statistik.

\section{$\underline{\text { Teori Z (Ouchi, 1981) }}$}

Latar belakang dan observasi teori ini didasarkan oleh Ouchi, setelah studi komparatif tentang gaya manajemen 
perusahaan Amerika dan Jepang. Ia menunjukkan perbedaan mendasar sebagai berikut: (1) Perusahaan Amerika memiliki mobilitas tinggi dan terbalik; perusahaan Jepang menyediakan pekerjaan seumur hidup untuk angkatan kerja mereka; (2) Organisasi Amerika lebih cenderung memberikan jalur karis yang sangat khusus bagi para manajer yang berbeda; dalam organisasi Jepang kebanyakan karyawan bergerak malalui berbagai fungsi dalam perjalanan karier mereka; (3) Perusahaan Amerika menggunakan sistem evaluasi dan insentif yang cepat dan eksplisit; perusahaan Jepang menggunakan sistem evaluasi yang lebih halus dan implisit; (4) Budaya Amerika sangat menghargai individu; budaya Jepang menghargai usaha bersama.

\section{Dengan demikian, Ouchi} menyarankan sebuah teori baru yang kemudian diberi nama Teori $\mathrm{Z}$ dengan mengikuti konsep dasar sebagai berikut: (1) Penekanan yang kuat dari budaya perusahaan: pengembangan dan implementasi filosofi perusahaan; (2) Pengujian secara hati-hati terhadap tingkat penerimaan pekerja, yang melibatkan sub budaya (dinamika kelompok, serikat pekerja, dan lain sebagaiya), menstabilkan pekerjaan, dan mengembangkan sistem untuk evaluasi

${ }^{1}$ Bolman dan Deal, Pendekatan Modern untuk Memahami dan Mengelola Organisasi (USA: Jossey-Bass, 1988) dan promosi yang lamban;

Menumbuhkan rasa hormat di antara para karyawan, mengintegrasikan semua personel ke dalam keluarga besar di dalam budaya perusahaan.

\section{Gambaran Umum tentang Kepemimpinan dan Gaya Manajemen ${ }^{1}$}

Berdasarkan teori manajemen yang ada di atas, pada dasarnya ada empat gaya manajemen yang sekarang dalam praktik organisasi dan perusahaan. Meskipun masing-masing gaya mengikuti teori tertentu sebagai fondasi dan kerangka acuannya, namun tidak ada gaya manajemen yang beroperasi sendiri-sendiri tanpa mengacu pada teori atau kerangka acuan yang lain. Karena tidak ada organisasi yang sederhana, gaya manajemennya rumit. Biasanya, setiap organisasi mengadopsi lebih dari satu kerangka acuan dan menyesuaikan diri dengan permintaan organisasi eksistensial dan mengembangkan kombinasi gayanya sendiri.

\section{Empat Kerangka Kepemimpinan dalam Organisasi \\ Struktural}

Kerangka struktural menekankan pentingnya peran dan hubungan formal. Struktur biasanya digambarkan dalam bagan organisasi dibuat agar sesuai dengan 
lingkungan dan teknologi organisasi. Organisasi mengalokasikan tanggungjawab kepada peserta ("pembagian kerja") dan membuat peraturan, kebijakan dan hierarki manajemen untuk mengkoordinasikan beragam aktivitas. Masalah muncul ketika struktur tidak sesuai dengan situasi. Pada tahap itu, beberapa bentuk reorganisasi diperlukan untuk memperbaiki ketidakcocokan.

\section{Sumber Daya Manusia}

Kerangka sumber daya manusia membentuk wilayahnya karena organisasi dihuni oleh masyarakat. Individu memiliki kebutuhan, perasaan dan prasangka. Mereka memiliki kapasitas yang besar untuk mempertahankan sikap dan kepercayaan lama. Dari perspektif sumber daya manusia, kunci keefektivitasannya adalah menyesuaikan organisasi dengan orangorang untuk menemukan bentuk organisasi yang memungkinkan orang menyelesaikan pekerjaan sambil merasa nyaman dengan apa yang mereka lakukan. Masalah timbul saat kebutuhan manusia tercekik.

\section{Politik}

Frekuensi politik memandang organisasi sebagai arena atau menakut-nakuti sumber daya dimana kekuasaan dan pengaruh terus-menerus mempengaruhi alokasi sumber daya di antara individu atau kelompok. Konflik diharapkan karena perbedaan kebutuhan, perspektif, dan gaya hidup di antara individu dan kelompok yang berbeda. Perundingan dan kompromi adalah bagian dari kehidupan organisasi sehari-hari. Koalisi yang terbentuk di sekitar kepentingan tertentu dapat berubah saat isu datang dan pergi. Masalah mungkin timbul karena kekuasaan tidak merata atau begitu tersebar luas sehingga sulit untuk menyelesaikan sesuatu. Solusi dikembangkan melalui keterampilan dan ketajaman politik - sama seperti yang disarankan Machiavellian berabad-abad yang lalu.

\section{Simbolis}

Kerangka simbolik meninggalkan asumsi rasionalitas yang muncul di masingmasing kerangka lainnya dan memperlakukan organisasi sebagai teater atau karnaval. Organisasi dipandang lebih disatukan oleh nilai dan budaya bersama, tujuan, cerita, pahlawan, dan mitos daripada peraturan, kebijakan, dan otoritas manajerial. Organisasi adalah drama; drama melibatkan aktor di dalam, dan bentuk pendengar dari luar.

Kesan berdasarkan apa yang mereka lihat terjadi di atas panggung. Masalah muncul saat aktor memainkan peran mereka dengan buruk. Bila simbol kehilangan potensinya, perbaikan datang melalui simbol, mitos dan sihir. 
Masing-masing memiliki visi realitas tersendiri. Hanya ketika manajer dapat melihat organisasi melalui empat orang, mereka cenderung menghargai kedalaman dan kompleksitas kehidupan organisasi. Manajer yang sukses mengandalkan secara intuitif pada kerangka yang berbeda, memadukanya dengan teori organisasi pribadi yang koheren dan pragmatis. Dipercaya bahwa pengantar eksplit dan landasan di keempat kerangka tersebut dapat memperkaya intuisi asli manajer manapun. Kesuksesan menjadi mungkin bagi sebagian besar yang tidak terlahir dengan kemampuan untuk memahami dan bertindak secara efektif dalam dunia yang rumit dan ambigu.

Organisasi ada terutama untuk mencapai tujuan yang telah ditetapkan. Untuk organisasi mana pun, ada struktur yang sesuai dengan tujuan, lingkungan, tekonologi, dan peserta. Organisasi bekerja paling efektif ketika kepemimpinan struktural. Turbulensi lingkungan dan preferensi pribadi peserta dibatasi oleh norma realitas. Spesialisasi memungkinkan tingkah keahlian dan kinerja individual yang lebih tinggi. Koordinasi dan pengendalian dilakukan dengan sebaik-baiknya melalui pelaksaan wewenang dan peraturan impersonal (untuk meminimalkan konflik), struktur dapat dirancang dan diimplementasikan secara sistematis. Masalah organisasi biasanya mencerminkan struktur yang tepat dan dapat dipecahkan melalui perancangan ulang dan reorganisasi.

\section{Gaya Kepemimpinan Struktural}

Gaya kepemimpinan struktural menekankan rasionalitas, analisis, logika, fakta dan data. Dipercaya kuat akan pentingnya struktur yang jelas dan sistem manajemen yang berkembang dengan baik. Percaya bahwa pemimpin yang baik adalah seseorang yang berpikir jernih, membuat keputusan yang baik, dan memiliki kemampuan analisis yang baik. Struktur dan sistem yang dirancang dengan baik akan menyelesaikan pekerjaan.

\section{Operasi Gaya Struktural}

Struktur Organisasi: Tiga Tingkat Struktural Utama

Struktur organisasi ini memiliki tiga tingkatan yakni: (1) Tingkat institusional. Tingkatan ini menghadapi lingkungan eksternal dan memelihara arus informasi dan sumber daya di seluruh batas organisasi (tanggung jawab eksekutif puncak); (2) Tingkat manajerial. Tingkatan ini mengkoordinasikan dan mengendalikan alur kerja, membuat keputusan, menyelesaikan konflik, dan menangani masalah yang muncul dalam situasi kerja (tanggung jawab manajer tingkat menengah); (3) Tingkat teknis. Tingkatan ini melakukan aktivitas spesifik yang diperlukan untuk mengubah 
bahan baku menjadi produk jadi (tanggung jawab pekerja dan panitera).

\section{$\underline{\text { Teori Motivasi dan Implikasinya Dalam }}$ Organisasi Gereja}

Bagianini berbicara tentang apa yang memotivasi orang. Pada tahun 1940, A. Maslow mengembangkan tentang Hierarki Kebutuhan berdasarkan tiga asumsi penting sebagai berikut: (1) Kebutuhan masyarakat yang diatur dalam hierarki; (2) Kebutuhan tingkat tinggi tidak akan memotivasi sampai tingkat bawah kebutuhan terpenuhi; (3) Ada lima kategori kebutuhan, yakni: kebutuhan fisiologis, kebutuhan keamanan, kebutuhan sosial, kebutuhan harga diri, kebutuhan aktualisasi diri.

Namun, teori Maslow tersebut diubah oleh Henry Murray, John Atkins, dan David McClelland yang melihat kekurangan teori tersebut. Kekurangan tersebut adalah seperti mengabaikan kebutuhan kognitif dan lain sebagainya. Mereka bertiga menyarankan agar semua orang memiliki tiga kebutuhan terutama dalam konteks manajemen organisasi. Rumusan tiga orang tersebut adalah: (1) Kebutuhan prestasi. Hal ini dilakukan dengan cara memotivasi dengan memberikan tugas yang manantang dengan tujuan yang dapat dicapai dengan jelas. Tingkatkan tanggung jawab melalui waktu; (2) Kebutuhan kekuatan. Memotivasi dengan membiarkan mereka memiliki kendali atas perencanaan dan berpartisipasi

dalam pengambilan keputusan;

Kebutuhan akan afiliasi. Memotivasi dengan membiarkan mereka tahu bahwa mereka adalah bagian dari tim. Berikan pujian dan biarkan mereka berinteraksi dengan orang lain. Teori di atas menyarankan bahwa para manajer harus mencocokkan pekerjaan dengan pekerjaan yang akan memenuhi kebutuhan mereka.

Pada tahun 1950, setelah mewawancarai 200 akuntan dan insinyur untuk mengetahui situasi di mana mereka merasa tidak puas, Frederich Herzberg mengembangkan teori dua faktor atau motivasi sebagai berikut: (1) Faktor 1: Kebutuhan Higiene (Kebutuhan fisiologis, keselamatan, dan sosial) harus dilakukan agar motivasi dapat berlangsung namun tidak memotivasi (faktor dasar); (2) Faktor 2: Motivator (esteem dan kebutuhan aktualisasi diri) - faktor biasa. Teori ini mengemukakan bahwa manajer perlu membangun tantangan dan kesempatan dalam pekerjaan. Herzberg kemudian mengembangkan sebuah konsep yang disebut job enrichment.

\section{Teori Ekuitas}

J. Stacy Adams mengembangkan Teori Motivasi Ekuitas. Orang termotivasi untuk mencari keadilan di antara penghargaan dan kinerjanya. Teori ini penting bagi manajer. Karena hal ini 
menunjukkan bahwa jika pekerja merasa bahwa mereka tidak diperlakukan secara adil, moral dan masalah kinerja akan terjadi.

\section{Teori Harapan}

Teori Harapan ini mengansumsikan bahwa motivasi didasarkan pada tiga faktor, yaitu: (1) Harapan - Kemungkinan menyelesaikan tugas; (2) Instrumentalitas Kepastian bahwa penghargaan akan mengikuti pertunjukan; (3) Valensi - Nilai yang ditempatkan pada berkat (sepadan).

Teori ini juga membantu para manajer karena hal ini menunjukkan bahwa untuk memotivasi para pekerja, mereka harus memahami tugas tersebut. Selain itu, kinerja superior harus diikat pada penghargaan; selanjutnya, penghargaan yang ditawarkan harus bermakna bagi para pekerja.

\section{Teori Ekspetasi Vroom}

Model dasarnya adalah Motivasi = Ekspetasi x Valensi (motivasi adalah fungsi antara harapan dan valensi). Ekspetasi berarti percaya usaha akan dihargai, sedangkan valensi berarti nilai yang melekat pada penghargaan tertentu.

Di sini terdapat model yang harus dikembangkan yakni, Motivasi $=[$ Harapan 1] x [Harapan 2] x ....x Valensi. Harapan 1 menjelaskan bahwa percaya usaha akan menghasilkan kinerja, sedangkan harapan 2 percaya bahwa kinerja akan menghasilkan penghargaan.
Teori Vroom membantu manajer untuk memahami bahwa dia harus memastikan pekerja memahami dengan jelas tugas yang harus dilakukan, dan penghargaan selalu dikaitkan dengan kinerja yang superior; selain itu penghargaan itu harus bermakna dan tidak sepadan dengan para pekerja.

\section{Reinforcement Theory}

Perilaku dapat dikendalikan melalui penggunaan penghargaan. Modifikasi perilaku atau teori pengkodisian operant (B. F. Skinner).

Jenis penunjangnya antara lain: (1) Penguatan positif; (2) Penguatan negatif; (3) Kepunahan; (4) Hukuman.

Memberikan pujian. Beritahukan kepada karyawan apa yang telah dilakukannya dengan benar. Beritahukan kepada karyawan mengapa perilaku itu penting. Jeda sebentar untuk membiarkan pujian masuk. Dorong kinerja berulang.

Pentingnya jenis penguatan, waktu dan urutan pemberian penguatan (kesesuaian, kedekatan atau harapan dan adil atau proposional).

\section{Teori Ekstensial-Futuristik (Joseph Tong)}

Karakteristik eksistensi manusia bersifat eksistensial dan futuristik. Termotivasi, yang tidak memperhitungkan, kedua aspek kini akan gagal. Di luar kemungkinan seseorang untuk 
diaktualisasikan sendiri, dia juga mampu dibuat baru dan membuat perbedaan dalam anugerah keselamatan yang menyelamatkan. Temukan seseorang, dan pimpin dia untuk menemukan dirinya sendiri; Menemukan dia dan membiarkan dia ditemukan di dalam Kristus dalam konteks komunitas orang percaya, dia pasti akan melakukan hal-hal besar di dalam Kerajaan Allah.

\section{$\underline{\text { Konsep Dasar Pemerintahan Gereja dan }}$ Administrasi Gereja}

Pemerintahan gereja adalah studi tentang bentuk pemerintahan gereja dan cara gereja dapat dijalankan secara tertib dan efektif. Studi tentang pemerintahan gereja mencakup namun tidak terbatas pada studi sistem pemerintahan, kantor gereja, otoritas dan operasi mereka, majelis gereja, prosedur parlementer, dan administrasi.

Gereja sebagai organisasi sukarela mempunyai aspek kemanusiaan dan hukum pemerintahan gereja. Kebutuhan operasi bisnis gereja harus baik dan tertib (1 Kor. $14: 40)$

Gereja sebagai Organisasi atau Majelis yang $\underline{\text { Disengaja }}$

Karakteristik Organisasi atau Majelis Deliberatif

Ini adalah kelompok orang yang independen atau otonom yang bertemu untuk menentukan dalam diskusi penuh dan bebas, sebuah tindakan yang harus diambil atas nama seluruh kelompok. Kelompok ini memiliki ukuran sedemikian rupa sehingga tingkat formalitas diperlukan dalam persidangan. Orang yang memiliki hak untuk berpartisipasi (anggota) biasanya bebas untuk bertindak di dalam majelis sesuai dengan penilaian mereka sendiri. Pendapat masing-masing anggotanya memiliki bobot yang sama seperti yang dinyatakan dalam pemungutan suara, dalam keputusan yang dibuat. Gagal untuk menyetujui keputusan tubuh bukan merupakan penarikan dari tubuh. Bahkan ketika ada orang yang tidak hadir, anggota hadir pada suatu tindakan pertemuan biasa atau mungkin yang disebut dengan benar untuk seluruh anggota, hanya tunduk pada batasan seperti yang mungkin ditetapkan oleh peraturan pemerintahan (seperti kuorum diskusi tentang masalah kuorum).

\section{Prinsip Dasar dalam Sebuah Organisasi Deliberatif}

Prinsip dasar dalam sebuah organisasi yang deliberatif adalah memiliki rasionalitas, konsistensi, koherensi, persamaan, ketertiban, efisiensi, brevity atau disederhanakan, holistik dan persatuan, kemanusiaan: tegas-teguh.

\section{KESIMPULAN}

Secara umum, manajemen organisasi dapat diartikan sebagai cara efektif untuk mendapatkan hal yang didapatkan melalui 
orang lain untuk mempertahankan tujuan dan koherensi organisasi. Kepemimpinan berkaitan dengan orang, sedangkan manajemen lebih memperhatikan tugas dan kinerjanya. Sejauh menyangkut organisasi, dua hal ini memiliki fungsi yang sama dalam mempromosikan kesejahteraan dan pengambangan organisasi yang sehat untuk mencapai tujuan organisasi.

\section{DAFTAR PUSTAKA}

Bolman, Lee G. and Terrence E. Deal. Modern Approaches to Understanding and managing Organization. San Francisco: JosseyBass Publishers, 1984.

Burke, W. Warner. Organization Development, Principles and Practices. Boston: Little, Brown and Company, 1982.

Dale, Robert D. Pastoral Leadership. Nashville: Abingdon Press, 1986.

Deal, Terrence E. and Allen A. Kennedy. Corporate Cultures, Reading. Mass.: Addison-Wesley Publishing Co.,1982.

Kouzez, James M. and Barry Z. Posner. The Leadership Challenge. San Francisco: Jossey-Bass Publishers, 1989.

Lindgren, Alvin J. and Norman Shawchuck. Management for Your Church. Indianapolis: Organizational Resources Press, 1984.
Peters, Thomas J. and Robert H. Waterman, Jr. In Search of Excellence. New York: Warner Books, 1984.

Quinn, Robert E. Beyond Rational Management. San Francisco: JosseyBass Publishers, 1989.

Robert, Henry. The Scott, Foresman Robert's Rule of Order Newly Revised, Glenview. Illinois: Scott Foreman Company, 1984.

Schein, Edgar H. Organizational Culture and Leadership. San Francisco: JosseyBass Publishers, 1985. 
Excelsis Deo: Jurnal Teologi, Misiologi, dan Pendidikan 